Hossein Mohammadi', Seyedmohammad Mirmehdi ${ }^{2+}$, Lisiane Nunes Hugen²

Keywords:

Polyethylene

Polypropylene

Natural fibers

Coupling agent

Mechanical properties

Histórico:

Recebido 23/06/2016 Aceito 17/11/2016

Palavras chave: Polietileno

Polipropileno

Fibras naturais

Agente de acoplamento

Propriedades mecânicas

+Correspondência: mohamadmirmehdi@yahoo.com

\section{RICE STRAW/THERMOPLASTIC COMPOSITE: EFFECT OF FILLER LOADING, POLYMER TYPE AND MOISTURE ABSORPTION ON THE PERFORMANCE}

ABSTRAT: Thermoplastic composites made with 45,60 and $75 \%$ of rice straw as filler and two types of thermoplastics, virgin polyethylene (PE) and polypropylene (PP) were evaluated. The final boards were made with and without maleic anhydride modified polypropylene (MAPP) at $2 \%$ of the total weight of each specimen. The flexural and tensile strengths were measured for dry composites and also measured after $24 \mathrm{~h}$ of water immersion of the composites (wet condition). By increasing the filler content, the flexural and tensile strengths and also the density of the specimens decreased. The type of matrix (PE or PP) did not affect significantly the flexural strength, but PP led to higher values of tensile strength for low fiber loadings (45\% and $60 \%)$. Coupling agents increased the flexural and tensile strength. After water immersion, modulus of elasticity and modulus of rupture were decreased, while tensile strength was less influenced.

\section{COMPÓSITO TERMOPLÁSTICO/PALHA DE ARROZ: EFEITO DA CARGA DE ENCHIMENTO, TIPO DE POLÍMERO EABSORÇÃO DE UMIDADE NO DESEMPENHO}

RESUMO: Foram avaliados compósitos termoplásticos feitos com 45, 60 e 75\% de palha de arroz como material de enchimento e dois tipos de termoplásticos, polietileno virgem (PE) e polipropileno (PP). As placas finais foram feitas com e sem polipropileno modificado com anidrido maleico (MAPP) a $2 \%$ do peso total de cada amostra. As resistências à flexão e à tração foram medidas para compósitos secos e também medidas após $24 \mathrm{~h}$ de imersão em água dos compósitos (condição úmida). Ao aumentar o teor de enchimento, as resistências à flexão e à tração e também a densidade dos matérias diminuíram. $O$ tipo de matriz (PE ou PP) não afetou significativamente a resistência à flexão, mas o PP levou os maiores valores de resistência à tração para baixas cargas de fibras (45\% e 60\%). Os agentes de acoplamento aumentaram a resistência à flexão e à tração. Após a imersão em água, o módulo de elasticidade e o módulo de ruptura diminuíram, enquanto que a resistência à tração foi menos influenciada. 


\section{INTRODUCTION}

As open-field burning of rice straw is being phased out in the north of Iran and government agencies are looking for new rice straw uses as a lignocellulosic residue. Any substance that contains carbohydrate polymers, cellulose and hemicellulose and an aromatic polymer, lignin, is a lignocellulosic. Lignocellulosic includes types of wood, agricultural crops, like kenaf; agricultural residues, such as bagasse, corn stalks and rice stalk, agricultural pruning residue such as date palm fronds and other plant substances (MIRMEHDI et al., 20I4). In general, what is true for wood is also true for other lignocellulosics even though they may differ in chemical composition and matrix morphology, in fact these kind of natural lignocellulosic fibers are available in many different forms and produce different properties when added to thermoplastics (GILBERT, I994; SANADI et al., 1995; ZAINI et al., 1995). These natural fibers are sustainable and available in large quantities and may be renewed annually. They are non-abrasive and possess high specific properties (ELGHARBAWY et al., 2016; DAYLAN; CILIZ, 2016).

The total area under rice in Iran is more than 600,000 ha and rice is grown in 15 provinces. However, more than 80 percent of rice area is distributed in the southern shores of the Caspian Sea (RANI, 2016) thus, there is a large amount of agricultural waste from rice harvests in these areas that can be considered and used as raw material in the manufacture of the lignocellulosic composites.

The properties of natural fiber/thermoplastic composites are influenced by the type of polymer, processing method and the type and content of natural fiber. The mechanical properties of wood fiber composites may not be significantly affected by wood fiber type (PARPARITA, 20I4), but it has also been reported that the type of lignocellulose fiber and the lignin, cellulose and hemicellulose content have a strong influence on mechanical properties (HABIBI et al., 2008). Polymers that have been used in natural fiber-reinforced thermoplastic composites include low and high-density polyethylene, polypropylene, polystyrene. The source of polymer as virgin or recycled material may (ZABIHZADEH et al., 20II) or may not (ADHIKARY et al., 2008) affect the properties of natural fiber-thermoplastic composites. Furthermore, the fiber content has a noticeable influence on the mechanical properties of these composites (YAO et al., 2008).

This is due to the hydrophobic and hydrophilic characteristics presented by the fibers and polymers, respectively (SILVA et al., 20I2), which interfere in fibermatrix adhesion. In this way, the chemical affinity between the components can be improved by the modification of the polymer by means of maleic anhydride (LÓPEZ MANCHADO et al., 2003; SOMBATSOMPOP et al., 2005; KIM et al., 2008; SOLEIMANI et al., 2008; SILVA et al., 20I2). Coupling agents also have a positive effect on the properties of agro-based fiber/thermoplastic composites (BAJWA et al., 20I5; ESSABIR et al., 20I6; POLETTO et al., 20I2; POLETTO; ZATTERA, 20I5; SOCCALINGAME et al., 20I5).

The wood fiber itself may absorb moisture before compounding with polymer to form the composite. Moisture uptake also can be a processing problem if precompounded pellets are used as feedstock in a forming operation. In these fields, the composites themselves can absorb moisture, which may adversely affect mechanical properties. It is sometimes claimed that moisture is not a problem for wood-plastic composites because the wood is totally encapsulated in polymer. In the case of total encapsulation, polymers would protect the wood from moisture because they are hydrophobic. At high percentages of wood flour, however, a composite still absorbs moisture (ZABIHZADEH et al., 20I I). Moisture is likely to affect the flexural and tensile strengths which are used in real conditions.

The flexural and tensile strengths in moist conditions are considered in the draft for development of the European standard BS EN I5534-I (2014). This paper aims to investigate the flexural and tensile strengths and density in thermoplastics filled with rice stalk evaluated under dry and wet conditions. The effect of the fiber content, coupling agent and type of polymer on flexural and tensile strengths was investigated.

\section{MATERIAL AND METHODS}

\section{Polymer matrix}

The thermoplastic polymers, polyethylene (PE) with a melt flow index of $18 \mathrm{~g} / 10 \mathrm{~min}$ at $190^{\circ} \mathrm{C}$ and a density of $960 \mathrm{~kg} \cdot \mathrm{m}^{-3}$ and polypropylene (PP) with a melt flow index of $5 \mathrm{~g} / 10 \mathrm{~min}$ at $190^{\circ} \mathrm{C}$ and a density of $918 \mathrm{~kg} \cdot \mathrm{m}^{-3}$ was used as the virgin powder polymer matrix and obtained from Arak Petrochemical Corporation.

\section{Filler}

The raw rice straw was obtained from local farms around Gorgan city in Iran and at 45\%, 60\% and 
$75 \%$ by weight used as the discontinuous phase (filler or reinforcement) in the composites and their size was 40-mesh. Rice straw is an agricultural by-product and the dry stalk after the grain and chaff have been removed.

Before grinding, the rice straw was oven-dried at $100 \pm 5^{\circ} \mathrm{C}$ for $24 \mathrm{~h}$ to expel moisture prior to blending with the polymers in order to encourage faster and uniform heating of the material. The moisture content of oven-dried fiber was reduced to about $3 \%$. The ovendried rice stalk was ground with a small laboratory grinder followed by passing through a 40-mesh screen, and then was stored in sealed plastic bags prior to compounding. Table I presents the average of chemical constituent of rice stalk (RAHNAMA et al., 20I3).

TABLE I Chemical constituents of rice stalks.

\begin{tabular}{cccc}
\hline $\begin{array}{c}\text { Cellulose } \\
(\%)\end{array}$ & $\begin{array}{c}\text { Hemicellulose } \\
(\%)\end{array}$ & $\begin{array}{c}\text { Lignin } \\
(\%)\end{array}$ & $\begin{array}{c}\text { Ash } \\
(\%)\end{array}$ \\
\hline $36-43$ & $26-27$ & $6.3-12.3$ & $12-13$ \\
\hline
\end{tabular}

\section{Compatibilizing agent}

The maleic anhydride grafted polypropylene (MAPP), was used as coupling agent for both types of composites with a fixed amount of $2 \%$ (by mass) in the sample preparation. MAPP was used to obtain better bonding between the hydrophilic fiber and the hydrophobic matrix polymer.

\section{Composites preparation}

Polymer, filler, and compatibilizer were initially weighed and bagged according to the various filler contents indicated in Table 2. After weighing the required quantity of materials for each treatment, a dry-blending method was used for compounding the materials.

To prepare the composites, each mixture was separately stored in a two-layer plastic bag to ensure

TABLE 2 Rice stalk (RS) / plastic composite formulations (\% by mass).

\begin{tabular}{cccc}
\hline Formulation & $\begin{array}{c}\text { Filler } \\
(\%)\end{array}$ & $\begin{array}{c}\text { Polymer } \\
(\%)\end{array}$ & $\begin{array}{c}\text { MAPP } \\
(\%)\end{array}$ \\
\hline 45\% RS, 55\% PE, NO MAPP & 45 & 55 & 0 \\
60\% RS, 40\% PE, NO MAPP & 60 & 40 & 0 \\
75\% RS, 25\% PE, NO MAPP & 75 & 25 & 0 \\
45\% RS, 53\% PE, 2\% MAPP & 45 & 53 & 2 \\
60\% RS, 38\% PE, 2\% MAPP & 60 & 38 & 2 \\
$75 \%$ RS, 23\% PE, 2\% MAPP & 75 & 23 & 2 \\
$45 \%$ RS, 55\% PP, NO MAPP & 45 & 55 & 0 \\
$60 \%$ RS, 40\% PP, NO MAPP & 60 & 40 & 0 \\
$75 \%$ RS, 25\% PP, NO MAPP & 75 & 25 & 0 \\
$45 \%$ RS, 53\% PP, 2\% MAPP & 45 & 53 & 2 \\
$60 \%$ RS, 38\% PP, 2\% MAPP & 60 & 38 & 2 \\
$75 \%$ RS, 23\% PP, 2\% MAPP & 75 & 23 & 2 \\
\hline
\end{tabular}

containment, and then spread as randomly as possible inside a metal frame and a wooden box with nominal dimensions of $25 \mathrm{~cm} \times 15 \mathrm{~cm} \times 1 \mathrm{~cm}$ in order to form a mat. This mat was cold pressed by using of a wooden sheet and wrapped in aluminum foil.

The final composites were made by pressing the wrapped mat between the hot plates of a compression press at $190^{\circ} \mathrm{C}$ for $7 \mathrm{~min}$ at 30-35 bar pressure, followed by removal of the pressure for I minute to allow steam to be ejected (Table 3). Then, for a second time the $30-$ 35 bar pressure was applied for $7 \mathrm{~min}$. The composite was cooled at 40 bar pressure by placing the composite between the two cold plates of another press for 5 min. The prepared composites were kept at room temperature for I 5 days in order to allow the condition of the composite to reach equilibrium.

TABLE 3 Hot-pressing process and conditions.

\begin{tabular}{ccccc} 
Conditions & \multicolumn{2}{c}{ Pre-pressing } & Pressing & Cold-Pressing \\
\hline Press pressure (bar) & $30-35$ & - & $30-35$ & 40 \\
Press temperature $\left({ }^{\circ} \mathrm{C}\right)$ & 190 & 190 & 190 & Room temp. \\
Press duration (min) & 7 & 1 & 7 & 5 \\
\hline
\end{tabular}

\section{Mechanical tests and conditioning}

All measurements were performed for three replicates of specimens and averaged to obtain the final result. An universal testing machine (Schenk) was used to obtain the flexural and tensile based on BS EN I5534-I (20/4) in dry and wet conditions. For the dry condition, the samples were oven dried at $100 \pm 2{ }^{\circ} \mathrm{C}$ for $24 \mathrm{~h}$. For the wet condition, the specimens were immersed in distilled water for $24 \mathrm{~h}$, and then, oven-dried for $24 \mathrm{~h}$.

Finally, the flexural and tensile strengths were measured in both conditions. This testing was carried out at room temperature. The obtained results presented here are the average of three measurements obtained for each kind of samples. Analysis of variance (ANOVA) was applied using Minitab 17.3 (Minitab Inc., State College, PA, USA) to determine significance of differences between means, at the significance level of $5 \%$.

\section{RESULTS AND DISCUSSION}

\section{Density}

It was found that the density of the composites ranges from 791 to $904 \mathrm{~kg} \cdot \mathrm{m}^{-3}$ (for PE) and from 757 to $892 \mathrm{~kg} \cdot \mathrm{m}^{-3}$ (for PP), depending on the straw fiber content (Figure I). Also, it can be seen that the composites 
made with MAPP have a slightly higher density, which is consistent with previous finding (ADHIKARY et al., 2008), where the density of composites increased as the loading of wood fiber increased, the addition of rice straw reduced the density of the composites.

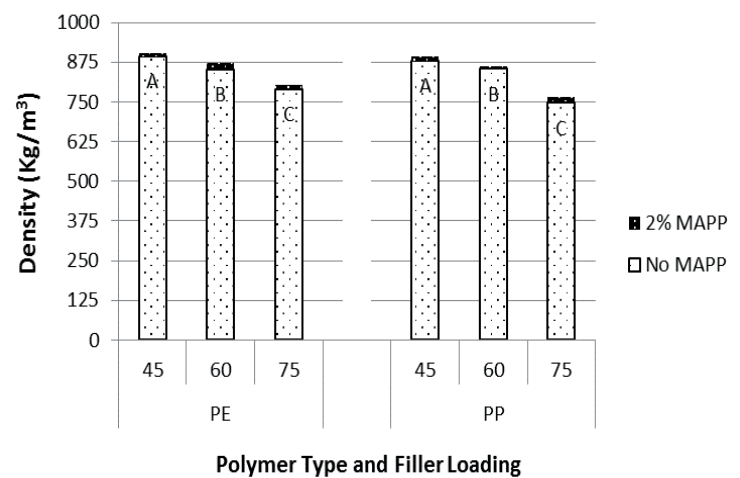

FIGURE I Density of rice straw/thermoplastic composite at the different filler loading (45\%, $60 \%$ or $75 \%)$, polymer type (PE or PP) and with/without MAPP. Different letters within a columns indicated significant difference at $p<0.05$.

This trend can be seen to be logical if we consider the higher density of wood materials and also the lower density of rice straw fiber compared with the density of polymer. Hence, increasing the amount of lignocellulose fiber leads to a lower density composite, which is very important from an industrial point of view.

\section{Flexural strength}

The modulus of rupture (MOR) obtained from the specimens under flexural loading at the different rice stalk level and different polymer matrices type were compared with each other and in dry and wet conditions as shown in Figure 2. The findings show that for higher fiber loading the flexural strength are decreased. Hence the general conclusion is that fiber content variation at the lower fiber to polymer ratios does not affect the flexural strength, while at higher fiber to polymer ratios (>50\%) the flexural strength declines.

Furthermore, composites with coupling agent have slightly higher flexural strength than those without coupling agent. This finding is also consistent with previous findings (SOCCALINGAME et al., 20I5; BAJWA et al., 20I5; ADHIKARY et al., 2008). The type of polymer matrix does not affect significantly on flexural strength at both dry and wet conditions. It is also clear that all flexural strengths in various formulations were reduced significantly in wet conditions.

\section{Dry Condition}

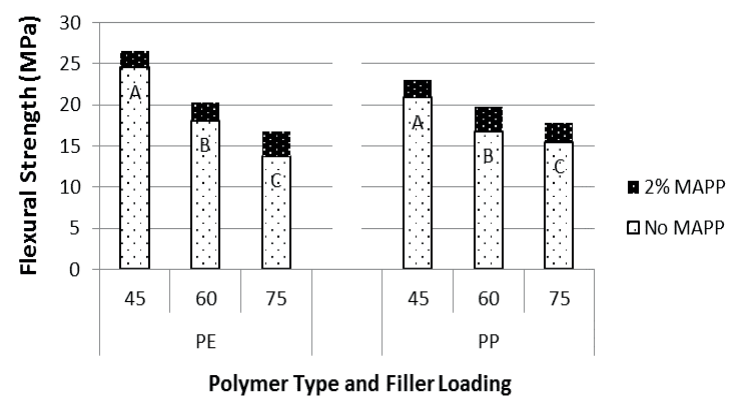

Wet Condition

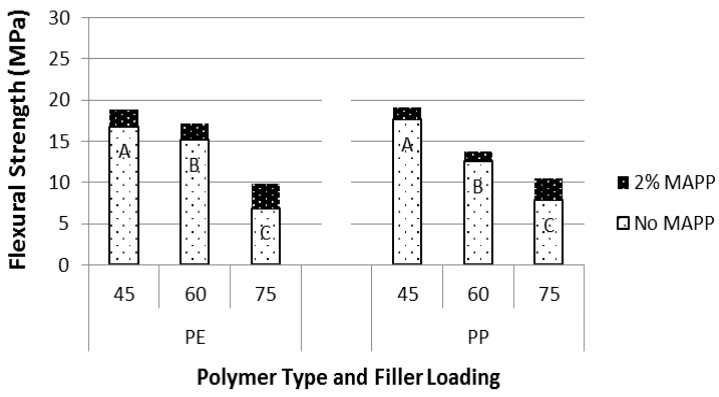

FIGURE 2 Flexural Strength of rice straw/thermoplastic composite at the different filler loading (45\%, $60 \%$ or $75 \%$ ), polymer type (PE or PP) and with/ without MAPP (dry and wet conditions). Different letters within a columns indicated significant difference at $p<0.05$.

\section{Flexural modulus}

The flexural samples were cut into rectangular specimens and the flexural modulus (MOE) was determined accordance with related standard. It is appeared that the effect of the filler loading was highly significant at both dry and wet conditions. In general, the flexural modulus decreased as the rice stalk level increased (Figure 3).

Furthermore, composites with coupling agent have slightly higher flexural modulus than those without coupling agent. This finding is also consistent with previous findings (SOCCALINGAME et al., 2015; BAJWA et al., 20I5; ADHIKARY et al., 2008). There were no significance differences between specimens made from PE and PP on flexural modulus at both dry and wet conditions.

\section{Tensile strength}

Filler plays an important role in determining the mechanical properties of cellulose filled/thermoplastic composites. The most crucial factor that affects the mechanical properties of the fiber reinforced materials is the fiber-matrix interfacial adhesion. The quality of 


\section{Dry Condition}

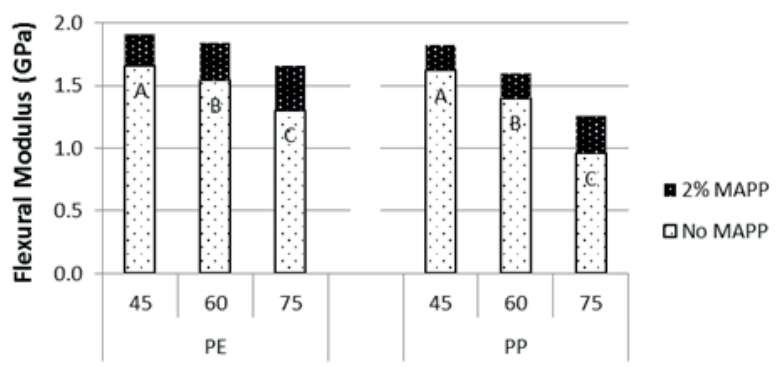

Polymer Type and Filler Loading

Wet Condition

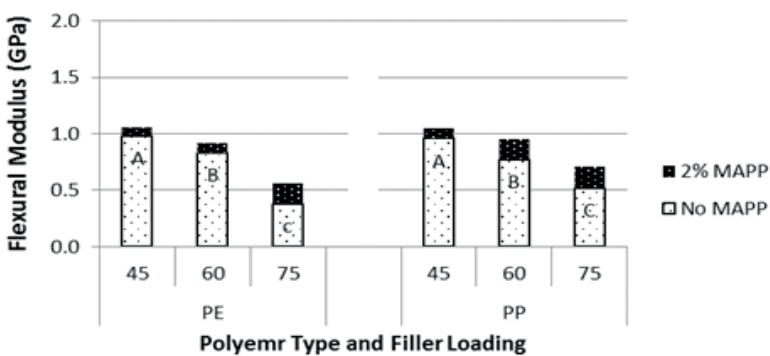

FIGURE 3 Flexural Modulus of rice straw/thermoplastic composite at the different filler loading (45\%, $60 \%$ or $75 \%$ ), polymer type (PE or PP) and with/ without MAPP (dry and wet conditions). Different letters within a columns indicated significant difference at $\mathrm{p}<0.05$.

interfacial bonding is determined by several factors, such as the nature of fiber and polymer components, the fiber aspect ratio, the processing method and the treatment of the fiber (MIRMEHDI et al., 20I4). Result of tensile strength of rice stalk/thermoplastic composites is shown in Figure 4.

The result showed that rice stalk/thermoplastic composites presented lower tensile strength values with increasing filler loading. The highest tensile strength was observed for specimens with $45 \%$ rice stalk with both PE and PP. There was statistical significance in tensile strength among the different filler loadings. Composites with PP matrix using $45 \%$ and $60 \%$ of fiber loading seems to present improved performance at tensile test than PE matrix in the same conditions.

Tensile strength is extremely dependable on interfacial adhesion between the phases. With adding MAPP, all of the samples had better tensile strength and its effect on tensile strength was more evident than flexural strength. This result is consistent with previous findings, which Mirmehdi et al. (20/4) showed that increasing filler content in PE compound resulted in reduction of tensile strength.

\section{Wet conditions}

The flexural and tensile strengths are reduced by increasing moisture content. Comparing the wet and dry conditions reveals that in wet conditions the existence of a coupling agent may slightly reduce water absorption especially at higher levels of fiber loading and improve the flexural and tensile strengths in wet conditions.

However, more content of coupling agent is probably required to reduce water absorption and increase flexural and tensile strengths. The result is reasonably consistent with Adhikary et al. (2008) on the measurement of other polymer properties. Furthermore, this finding might be important from the point of view of economical savings during industrial production, particularly for Iranian manufacturers. Coupling agent, fiber loading and wetting conditions significantly influence the flexural and tensile strengths. High fiber loading should be avoided in wet conditions (MADHOUSHI et al., 2009).

Composites with coupling agent have better dispersion and better interfacial strength compared to the composites without coupling agent (WALKER, 2006). After water immersion, the MOE was reduced

\section{Dry Condition}

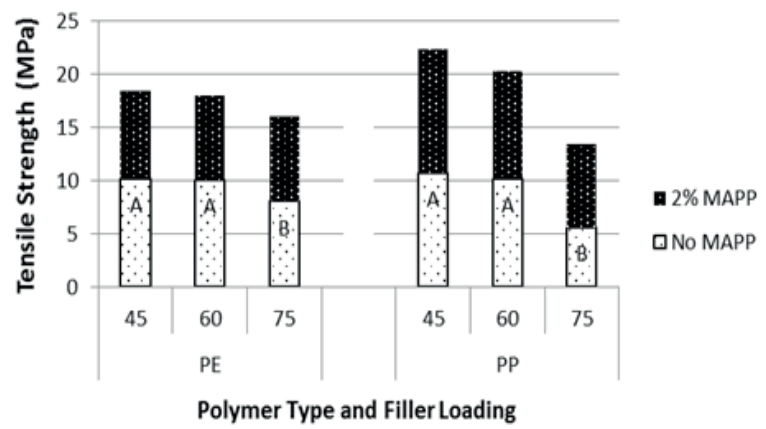

Wet Condition

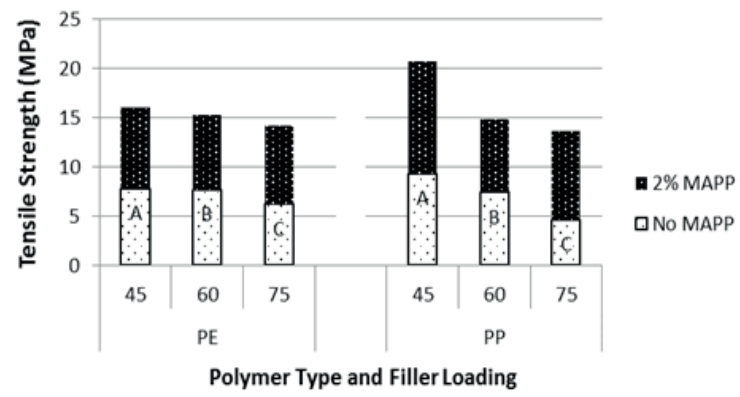

FIGURE 4 Tensile strength of rice straw/thermoplastic composite at the different filler loading (45\%, 60\% or $75 \%$ ), polymer type and with/without MAPP (dry and wet conditions). Different letters within a columns indicated significant difference at $p<0.05$. 
more than MOR values. Tensile strength showed the lowest reduction due to wetting.

\section{CONCLUSIONS}

The density of rice straw fiber-polymer composites decreased as the amount of fiber increased. The flexural and tensile strengths increased with using coupling agent and decreased when fiber loading is higher than $50 \%$. After immersion, the values of MOE, MOR and tensile strength decreased for all formulations. The type of polymer matrix does not affect significantly the flexural strength, but PP matrix seems to present improved tensile strength than PE matrix when using $45 \%$ and $60 \%$ of fiber loading.

\section{REFERENCES}

ADHIKARY, K. B.; PANG, S.; STAIGER, M. P. Dimensional stability and mechanical behaviour of wood-plastic composites based on recycled and virgin high-density polyethylene (HDPE). Composites part B, v. 39, n. 5, p. $807-815,2008$.

BAJWA, D. S; BAJWA, S. G; HOLT, G. A. Impact of biofibers and coupling agents on the weathering characteristics of composites. Polymer Degradation Stability, v. 120, p. 212-219, 2015.

BS EN I5534-I:20I4. Wood-plastics composites (WPC). Test methods for characterization of WPC materials and products.

DAYLAN, B.; CILIZ, N. Life cycle assessment and environmental life cycle costing analysis of lignocellulosic bioethanol as an alternative transportation fuel. Renewable Energy, v. 89, p. 578-587, 2016.

ELGHARBAWY, A. A.; ALAM, M. D. Z.; MONIRUZZAMAN, M.; GOTO, $M$. lonic liquid pretreatment as emerging approaches for enhanced enzymatic hydrolysis of lignocellulosic biomass. Biochemical Engineerning Journal, v.109, p. 252-267, 2016.

ESSABIR, H.; BENSALAH, M. O.; RODRIGUE, D.; BOUHFID, R.; QAISS, A. Biocomposites based on Argan nut shell and a polymer matrix: effect of filler content and coupling agent. Carbohydrate Polymers, v. I43, n. 5, p. 70-83, 2016.

GILBERT, R. D. Cellulosic polymers, blends and composites. New York: Hanser Publishers; 1994.

HABIBI, Y.; ELZAWAWY, W. K.; IBRAHIM, M. M.; DUFRESNE, A. Processing and characterization of reinforced polyethylene composites made with lignocellulosic fibers from egyptian agro-industrial residues. Composites Science and Technology, v.68, n. 7-8, p. 1877-1885, 2008.
KIM, S.; MOON, J.; KIM, G.; HÁ, S. Mechanical properties of polypropylene/natural fiber composites: Comparison of wood fiber and cotton fiber. Polymer Testing, v. 27, n.7, p. $80 \mathrm{I}-806,2008$.

LÓPEZ MANCHADO, M. A.; ARROYO, M.; BIAGIOTTI, J.; KENNY, J. M. Enhancement of mechanical properties and interfacial adhesion of PP/EPDM/Flax fiber composites using maleic anhydride as a compatibilizer. Journal of Applied Polymer Science, v. 90, n.8, p. 2170-2178, 2003.

MADHOUSHI, M.; NADALIZADEH, H.; ANSELL, M. P. Withdrawal strength of fasteners in rice straw fibrethermoplastic composites under dry and wet conditions. Polymer Testing, v. 28, n. 3, p. 30I-306, 2009.

MIRMEHDI, S. M.; ZEINALY, F.; DABBAGH, F. Date palm wood flour as filler of linear low-density polyethylene. Composites Part B: Engineering, v. 56, p. 137-|4|, 2014.

PĂRPĂRIŢ̆, E.; DARIE, R. N.; POPESCU, C. M.; UDDIN, M. D. A.; Vasile, C. Structure-morphology-mechanical properties relationship of some polypropylene/ lignocellulosic composites. Materials and Design, v. 56, p. $763-772,2014$

POLETTO, M.; ZENI, M.; ZATTERA, A. J. Effects of wood flour addition and coupling agent content on mechanical properties of recycled polystyrene/wood flour composites. Journal of Thermoplastic Composite Materials, v. 25, p. $821-833,2012$.

POLETTO, M.; ZATTERA, A. J. Mechanical and dynamic mechanical properties of polystyrene composites reinforced with cellulose fibers: coupling agent effect. Journal of Thermoplastic Composites, v. 9, p. I-13, 2015.

RAHNAMA, N.; MAMAT, S.; SHAH, U. K.; LING, F. H.; ABDUL RAHMAN, N. A.; ARIFF, A. B. Effect of alkali pretreatment of rice straw on cellulose and xylanase production by local trichoderma harzianum SNRS3 under solid state fermentation. Bioresources, v. 8, n. 2, p. 288I-2896, 2013.

RANI, N. S. International rice commission newsletter: the rice situation in iran. Available at: http://www.fao.org/ docrep/003/w8595t/w8595t05.htm\#P0_0. Accessed in: II April 2016.

SANADI, A. R.; WALZ, K.; WEILOCH, L.; JACOBSON, R. E.; CAULIFIELD, D. F; ROWELL, R. M. Effect of matrix modification on lignocellulosic composite. In: Proceedings of 3rd international conference on wood fiber-plastic composites, Madison, WI; May p. I-3, 1995.

SILVA, J. L.; PANZERA, T; CHRISTOFORO, A.; RUBIO, J.; SCARPA, F. Micromechanical Analysis of Hybrid Composites Reinforced with Unidirectional Natural Fibres, Silica Microparticles and Maleic. Materials Research, v. 15, n. 6, p.1003-1012, 2012. 
SOCCALINGAME, L.; BOURMAUD, A.; PERRIN, D.; BENEZET, J. C.; BERGERET, A. Reprocessing of wood flour reinforced polypropylene composites: Impact of particle size and coupling agent on composite and particle properties. Polymer Degradation Stability, v. II3, p. 72-85, 2015.

SOLEIMANI, M.; TABIL, L.; PANIGRAHI, S.; OPOKU, A. The effect of fiber pretreatment and compatibilizer on mechanical and physical properties of flax fiberpolypropylene composites. Journal of Polymers and the Environment, v. I6, n. I, p. 74-82, 2008.

SOMBATSOMPOP, N.; YOTINWATTANAKUMTORN, C.; THONGPIN, C. Influence of type and concentration of maleic anhydride grafted polypropylene and impact modifiers on mechanical properties of PP/Wood sawdust composites. Journal of Applied Polymer Science, v. 97, n. 2, p. 475-484, 2005.
WALKER, J. C. F. Primary wood processing: principles and practice. 2nd ed. Dordrecht: Springer Science \& Business Media, 2006, 396p.

YAO, F; WU, Q.; LEI, Y.; YANJUN, X. Rice straw fiberreinforced high-density polyethylene composite: effect of fiber type and loading. Industrial Crops and Products, v. 28, n. I, p. 63-72, 2008.

ZABIHZADEH, S. M.; OMIDVAR, A.; MARANDI, M. A. B.; MIRMEHDI, S. M.; DASTOORIAN, F. Physical and mechanical properties of rapeseed waste-filled LLDPE composites. Journal of Thermoplastic Composite Materials, v. 24, n. 4, p. 447-458, 201 I.

ZAINI, M. J.; FAUD, M. Y. A.; ISMAIL, Z.; MANSOR, M. S.; MUSTAFAH, J. The effect of filler content and size on the mechanical properties of polypropylene/oil palm wood flour composites. Polymer International, v. 40, p. 5I- 55, 1995. 
